Vol. 1, No. 1, Desember 2020

\title{
PENYULUHAN TENTANG PENGELOLAAN KEUANGAN DAN ADMINISTRASI USAHA PADA KELOMPOK INDUSTRI RUMAHTANGGA DI DESA MADANA KECAMATAN TANJUNG KABUPATEN LOMBOK UTARA
}

\author{
Emi Salmah ${ }^{1}$ ), Titi Yuniarti ${ }^{2)}$, Wahidin ${ }^{3)}$, Eka Agustiani ${ }^{4)}$ \\ 1,2,3, 4 Jurusan IImu Ekonomi dan Studi Pembangunan \\ Fakultas Ekonomi dan Bisnis Universitas Mataram, NTB \\ Emai; emisalmah0101@gmail.com
}

\section{Article History:}

Received: -

Revised: -

Accepted: -
Abstrak: Kegiatan Penyuluhan dilakukan di Desa Medane Kecamatan Tanjung Kabupaten Lombok Utara. Kegiatan ini bertujuan untuk memberikan motivasi kepada para ibu-ibu yang tergabung dalam industri rumahtangga untuk membuat catatan keuangan. Diharapkan setelah para ibu-ibu mengikuti penyuluhan ini, mereka bisa menghitung penerimaan dan pengeluaran dari usaha yang dilakukan. Pada akhirnya timbul kesadaran dari para ibu-ibu yang tergabung pada industri rumahtangga dalam hal pengelolaan keuangan. Bentuk dari kegiatannya adalah Ceramah yang dilanjutkan dengan diskusi ( Tanya jawab) interaktif untuk mempertajam pokok permasalahan yang disampikan yang dipandu oleh anggota tim pengabdian. Dari hasil diskusi dapat diketahui bahwa ibu ibu yang tergabung dalam kelopmpok industri rumahtangga di Desa Medana sangat bersemangat dan mendukung kegiatan penyuluhan dan bimbingan dengan pokok bahasan sebagaimana yang disampaikan oleh Tim Pengabdian Kepada Masyarakat. Mereka pada umumnya baru memulai lagi usahanya, setelah Tahun 2018 peralatan yang dipakai untuk usaha sudah hancur dan rusak akibat bencana Gempa Bumi. Usaha mereka antara lain, Sate ikan, catering, kerupuk, minyak goreng, VCO, Kue tradisonal, kerajinan tangan (anyaman Inke) dll. Untuk itu penyuluhan dan bimbingan seperti ini perlu terus ditingktkan dan dikembangkan kearah 
Emi Salmah, dkk: Penyuluhan Tentang Pengelolaan Keuangan dan Administrasi........

yang lebih kreatif dan inovatif pada usaha lainnya secara intensif dan kontinyu, sehingga masyarakat dapat meningktakan keterampilan dan pengetahuannya, dimana hal ini akan berdampak pada terjadinya perkembangan usaha ibu ibu kelompok industri rumahtangga dan terjadi peningkatan pendapatan.

Kata Kunci: Pengelolaan Keuangan, Administrasi Usaha, Kelompok Industri Rumahtangga 
Vol. 1, No. 1, Desember 2020

\section{PENDAHULUAN}

Pembangunan Industri termasuk industri kecil, telah banyak memberikan hasil dalam peningkatan kesejahteraan masyarakat, pemerataan dan penyerapan tenaga kerja karena industri semacam ini merupakan usaha produktif dan kreatif yang dijalankan oleh rakyat meskipun dengan modal dan teknologi yang terbatas.

Seiring dengan meningkatnya dan beranekaragamnya kebutuhan masyarakat serta dengan perkembangan pariwisata, maka prospek perkembangan industri kecil dan kerajinan mempunyai korelasi positif terhadap selera, kebutuhan masyarakat dan perkembangan pariwisata. Oleh karena itu industri kecil dan kerajinan di Nusa Tenggara Barat sangat potensial untuk dikembangkan , karena dapat mendukung pariwisata dan mampu menyerap tenaga kerja dan industri yang dapat melestarikan kebudayaan lokal.

Salah satu bentuk industri kecil dan kerjinan tersebut adalah industri makanan ringan, membuat minyak kelapa ( minyak goreng ) dan VCO, kerupuk opak opak, kerajinan tangan lainnya yang dikelola secara skala rumahtangga. Usaha ini merupakan salah satu usaha yang tumbuh dan berkembang yang memanfaatkan potensi atau sumberdaya lokal yang umumnya berlangsung secara bertahap dan berkesinambungan. Pendidikan mereka rata-rata hanya tamat Sekolah Menengah Pertama ( SMP ) bahkan ada yang sama sekali tidak pernah sekolah. Keadaan ini menyebabkan pengelolaan usaha terutama berkaitan dengan keuangan dan administrasi usaha tidak dilakukan secara sempurnah seperti usahausaha lainnya, namun dihadapkan pada kenyataan bahwa mereka belum mengelola keuangannya secara baik-baik dan rata-rata mereka tidak mempunyai simpanan ( tabungan ).

Jumlah perempuan perajin industri rumahtangga di Desa Medana sebanyak 146 orang. Mereka telah terbukti mampu memberikan kontribusi yang cukup besar bagi ekonomi rumahtangga.

Berdasarkan masalah tersebut dan hasil observasi awal di Desa Medana, menurut tim Pengabdian Kepada Masyarakat Fakultas Ekonomi dan Bisnis ( FEB), Jurusan Ilmu Ekonomi dan Studi Pembangunan, merasa perlu mengadakan kegiatan pembinaan dalam pengelolaan ( manajemen ) usaha khususnya masalah keuangan, karena selama ini hasil penjualan dan input yang digunakan dalam proses produksi tidak dilakukan pencatatan/pembukuan sehingga dalam penentuan harga pokok biasanya tidak wajar. Oleh karena itu pelatihan dan penyuluhan ini 
dirasakan perlu agar dapat berusaha kearah yang lebih baik untuk usaha mereka dimasa akan datang.

Pada hakekatnya penyuluhan ini ditujukan pada Ibu-ibu yang tergabung dalam kelompok industri rumahtangga di Desa Medane Kecamatan Tanjung, Kabupaten Lombok Utara, yang lebih banyak berperan dalam pelaksanaan usaha. Secara terinci tujuan dari penyuluhan ini adalah :

1. Memberikan motivasi pada Ibu-ibu yang tergabung dalam industri rumahtangga untuk membuat catatan (pembukuan) mengenai penerimaan dan pengeluaran usaha mereka.

2. Memberikan tambahan pengetahuan tentang cara-cara menghitung penerimaan dan pengeluaran dari usaha yang dilakukan

3. Memotivasi mereka agar mau menabung sebagian dari penerimaan meraka, agar tidak kesulitan modal pada saat mau membeli bahan baku.

\section{METODE KEGIATAN}

Kegiatan pengabdian pada masyarakat ini dilakukan dengan cara tatap muka secara langsung melalui kegiatan ceramah dan diskusi interaktif. Penyuluhan dilakukan terhadap ibu ibu yang tergabung dalam kelompok industri rumahtangga.

Kegiatan penyuluhan ini dilaksanakan di Aula Kantor Desa Medane, pada Hari Jum'at, tanggal 30 Agustur 2019 yang dihadiri oleh sebanyak 20 orang ibu ibu yang tergabung dalam kelompok usaha.

\section{Materi Materi Yang Disampaikan Dalam Pelatihan Ini Antara Lain:}

MATERI I ; Manajemen Wiraswasta,

Manajemen pada hakekatnya berhubungan dengan usaha untuk mencapai tujuan tertentu dengan menggunakan faktor-faktor produksi sebaik mungkin melalui orang-orang yang bekerja dalam usaha tertentu. Apabila kita ingin mencapai suatu tujuan tertentu diperlukan suatu pemutusan pemikiran, bagaimana mengelola tenaga yang tersedia, bagaimana mengelola bahan-bahan, alat-alat, bagaimana menggunakan waktu dan sebagainya. Pengetahuan tentang manajemen merupakan 
Vol. 1, No. 1, Desember 2020

pedoman untuk berusaha, pedoman untuk melaksanakan dan bertindak, sekaligus sebagai dasar dalam pelaksanaan usaha yang produktif, sehingga dapat dicapai sebagaimana yang diharapkam.

Didalam menjalankan dan mengembangkan usahanya, pengusaha selalu berpegang pada prinsip-prinsip manajemen. Dalam jalan menggunakan prinsip-prinsip manajemen, para wiraswastawan akan dapat menghindari/mengurangi kesalahan-kesalahan, pemborosanpemborosan dalam proses produksinya, serta dapat diperhitungkan kemungkinan usahanya.

Wirastawan pada dasarnya disebut juga sebagai manajer yang dapat merumuskan tujuan usahanya, dapat membuat penyusunan rencana produksinya, bagaimana memasarkan hasil produksinya, bagaimana melakukan pengendalian dan lain-lain.

Salah satu fungsi manajer adalah menyusun rencana yang membuat perumusan tujuan dan saran-saran serta tahapan kegiatan untuk mencapai tujuan usaha. Sebagai manajer mereka harus mampu menjalankan fungsi-fungsi manajemen seperti perencanaan. Pelaksanaan dan pengendalian.

Sebagai manajer wiraswasta harus mampu mengelola semua sumber, termasuk menggerakan orang lain dan atau bawahannya untuk mencapai tujuan usaha. Sebagai manajer mereka harus mampu menjalankan fungsi-fungsi manajemen seperti perencanaan, pelaksannan dan pengendalian.

Rencana merupakan tolok ukur untuk pengendalian pelaksanaan, untuk evaluasi dan dalam proses pelaksanaanya. Dalam hal tersebut di atas, seorang manajer sangat berperan dalam menentukan pendayagunaan sumber-sumber atau faktor-faktor produksi yang tersedia dengan menggunakan orang-orang yang bekerja dalam perusahaan. Dengan kata lain manajemen adalah ilmu dan seni bagaiman menggerakan orang lain untuk dapat menyelesaikan pekerjaan sehingga dapat mencapai tujuan yang telah ditentukan.

Disamping membuat perencanaan, seorang waraswatawan juga berfungsi untuk melakukan pengawasan, pengendalian, misalnya dalam hal pengendalian produksi. Setelah terlebih dahulu membuat perencanaan produksi yang baik dan mantap, maka dilanjutkan dengan tahapan pengendalian kegiatan produksi (proses produksi). Untuk dapat 
menghasilkan barang-barang yang baik sebagaimana yang telah direncakan dan diharapkan misalnya tepat jumlahnya, tepat waktunya, tepat biayanya dan lain-lain, maka diperlukan adanya pengendalian produksi.

Pengawasan adalah merupakan kegiatan yang dilakukan selama produksi berjalan. Untuk menghindari atau mengidentifikasi penyimpangan-penyimpangan dari rencana yang telah ditetapkan bersama. Pengawasan dan pengendalian diperlukan:

1. Agar pelaksanaan kegiatan tidak menyimpang dari rencana yang sudah ditentukan

2. Agar terhindar dari pemborosan, kebocoran, dan lain-lain

3. Agar kegiatan suatu program dapat tercapai dengan baik

\section{Pengertian Dan Sikap Kewiraswastaan}

Dalam pelaksanaan pembangunan di negara kita Republik Indonesia mengharapkan dan menuntut tersedianya masyarakat/penduduk yang selalu siap untuk berperan dalam pembangunan dengan memiliki kepribadian, kepercayaan pada diri sendiri, berani mengambil resiko, bergairah untuk berusaha/bekerja, mempunyai inisiatif dan semangat tinggi, ulet dan seterusnya. Dengan kata lain dalam pembangunan nasional kita membutuhkan manusia yang dapat berwiraswasta dan mempunyai jiwa wiraswasta.

Wiraswasta berasal dari:

Wira, artinya : Berani, perkasa, teladan dan pelopor

Swa, artinya : Sendiri

Sta, artinya : Berdiri

Jadi secara harfiaah kewiraswastaan berarti suatu keberanian untuk berdiri di atas atau kemampuan untuk menjadi pelopor dalam melakukan suatu usaha secara mandiri. Dalam wawasan yang luas kewiraswastaan adalah suatu kepribadian, semangat, keahlian dan kemampuan dalam melakukan usaha secara mandiri dan memajukan diri sendiri serta lingkungannya.

Kewirawastaan berarti suatu kemampuan melakukan usaha, mengkombinasi dan mengelola sumberdaya yang tersedia untuk mendapatkan kemanfaatnan yang sebesar-besarnya. Seorang wiraswastawan mempunyai sifat kepeloporan, kemajuan selalu mau tumbuh dan berkembang, dan berusaha berdiri sendiri serta menciptakan lapangan kerja. 
Vol. 1, No. 1, Desember 2020

\section{Beberapa Sikap Kewiraswastaan Yang Harus Dimiliki}

\section{Kreatif}

Kewiraswastaan disamping harus pandai mencari kebutuhan, ia juga harus cekatan memenuhi kebutuhannya itu. Oleh karena itu ia harus memiliki daya pikir kreatif dan sikap mental kreatif. Sikap mental kreatif ini mengandung unsur-unsur sebagai berikut :

$\mathrm{K}=$ Keinginan untuk maju

$\mathrm{R}=$ Rasa ingin tahu yang kuat

$\mathrm{E}=$ Entusias atau semangat yang membara

$A=$ Analisa yang sistimatis

$\mathrm{T}=$ Terbuka menerima pendapat orang lain dan pembahruan

$\mathrm{I}=$ Doronagn usaha kuat

$\mathrm{F}=$ Pikiran yang terkonsentrasi

Apabila sikap kreatif tersebut memiliki dan diterapkan dalam usahanya maka berat kemungkinan wiraswastawan berhasil.

\section{Percaya pada diri sendiri}

Percaya pada diri sendiri mengandung makna bahwa individu itu potensi/kekuatan pada dirinya disamping kelemahan yang dimilikinya. mengembangkan dirinya.

\section{Ulet, Tekun, Dan Rasional}

Seorang wirastawan tidak lekas putus asa menghadapi segala tantangan, memiliki kesabaran, tidak cepat merasa putus asa, selalu menggunakan pikiran sehat dalam mengambil keputusan dan tidak bersifat emosional.

\section{Berani Menanggung Resiko}

Apabila orang berusaha, baik pada waktu akan memulai usahanya maupun dalam proses pelaksanaan usahanya seringkali ia menghadapi resiko. Sebagai pengusaha yang baik ia selalu berusaha untuk menghindari bahkan kalau dapat meniadakan resiko tertentu.

\section{Berwawasan Masa Depan}

Wiraswasta harus berorientasi pada masa depan yang lebih baik, bukan hanya pada keadaan masa sekarang. Usaha-usaha yang dilakukan selalu mempunyai keterkaitan dengan masyarakat banyak terutama dari segi kepercayaan masyarakat. 


\section{MATERI II. Pembukuan dan Administrasi,}

Tanpa disadari, dalam kehidupan sehari-hari sebenarnya kita telah melakukan pembukuan. seorang pengrajin gerabah atau ukir-ukiran membuat catatan bahan baku yang telah dipakai dan tenaga kerja yang telah dipekerjakan serta biaya-biaya lainnya yang telah dikeluarkan untuk membuat atau menghasilkan satu unit hasil kerja, maka pengerajin tadi pada dasarnya telah menerapkan teknik pembukuan secara sederhana.

seorang ibu rumah tangga merasa perlu mencatat pengeluara (belanja) keluarga kemudian melakukan pencatatan pengeluaran tersebut dalam catatan kecil agar dia dapat mengetahui jumlah pengeluaran (belanja) sampai tanggal tertentu dan berapa rata-rata biaya hidup keluarga selama satu bulan atau satu tahun. Kasus sederhana lainnya, seorang pemilik warung yang menjual kebutuhan barang-barang pokok (sembako) dan barang kelontong lainnya membuat catatan sederhana siapa saja yang berhutang di warungnya. Untuk ukuran yang lebih besar, misalnya dalam perusahaan besar, penerapan pengetahuan bidang akutansu lebih luas dan makin banyak dilakukan. mengapa mereka melakukan itu ? pada dasarnya karena kebutuhan mereka akan informasi yang dapat membantu dalam proses menentukan tindakan yang diperlukan.

Catatan yang dibuat oleh pengerajin dapat membantu dirinya mengetahui berapa pengorbanan yang dikelurakan untuk menghasilkan suatu barang yang dihasilkan, hal ini sangat penting atau mutlak dijadikan dasar penentuan harga jual yang wajar dari barang yang dihasilkan, bahkan dengan catatan tersebut perajin dapat memutuskan bahan-bahan yang akan dibeli atau dibutuhkan. informasi tentang harga didalamnya dapat dijadikan pedoman ketika membeli di bulan berikutnya dan lain-lain. demikian juga catatan belanja harian yang dibuat Ibu-ibu rumah tangga dapat dipakai sebagai informasi, sehingga dapat diputuskan apakah dia harus menambah atau mengurangi pengeluaran tertentu apakah dia harus menunda membeli alat-alat tertentu atau apakah dia harus menunda pembelian alat-alat tertentu atau apakah mungkin untuk menambah fasilitas bagian ruang temapt tinggalnya atau membuat catatan orangorang yang berhutang di warungnya, dari catatan tersebut pemilik warung dapat mengetahui siapa yang dianggap masih boleh dan pantas berhutang pada periode yang akan datang dan lain-lain. 
Vol. 1, No. 1, Desember 2020

\section{MATERI III: Metode Pengembangan Usaha}

Pengembangan usaha adalah upaya memperluas usaha yang ada seperti memperluas kios yang ada, menambah jenis dan jumlah barang dagangan, membuka kios sejenis di tempat yang lain, atau membuka usaha baru yang berbeda dengan usaha yang dikelola sebelumnya. anda telah memiliki kios kelontong karena menurut pengamatan anda dilokasi tersebut belum tersedia kios (toko) yang menjual alat tulis kantor, padahal disitu banyak orang membutuhkannya, maka kemudian anda membuka kios ( toko ) alat-alat tulis kantor, disamping anda telah memiliki toko kelontong,

Dalam upaya pengembangan usaha ini, ada aspek-aspek penting yang perlu memperoleh perhatian yaitu : aspek pasar, aspek teknis, aspek pengelolaan organisasi dan aspek ekonomi atau keuangan.

\section{Ada beberapa cara untuk mengetahui perkiraan jumlah permintaan barang :}

a. Mempelajari pengalaman penjualan yang telah ada. Anda dapat melihatnya dari catatan hasil penjualan bulanan atau tahunan.

b. Menurut jumlah dan status sosial ekonomi penduduk. Berapa jumlah penduduk diwilayah tempat usaha anda ? bagaimana status ekonominya, kaya, menengah, atau golongan miskin (bawah). Berapa KK penduduk yang bertempat tinggal disekitar tempat jualan anda. Mereka inilah yang mungkin akan menjadi pembeli utama yang dapat anda penuhi.

c. Apakah ada pesaing, usaha sejenis yang ada di dekat tempat usaha anda, siapa dan berapa banyak pesaing tersebut. Usaha sejenis disekitar tempat usaha atau calon tempat pengembangan usaha baru, adalah pesaing yang harus anda kendalikan. Anda harus memeperhatikan dengan cermat.

Cara Pelayanan

a. Ramah dan akrab dengan pembeli

b. Keluwesan dalam tawar menawar dengan pembeli.

Aspek Teknis

Kalau ketiga hal tersebut diatas ( calaon pembeli, permintaan barang dan keadaan pesaing serta cara pelayanan sudah anda pahami secara cermat, langkah-langkah selanjutnya adalah memperhitungkan :

a. Berapa kemampuan volume usaha yang diinginkan

b. Darimana barang dagangan diperoleh

c. Perlengkapan apa yang diperlukan 
d. Dimana lokasinya

e. Bagaimana mempromosikan usaha

Volume usaha disebut juga omzet usaha, artinya adalah besarnya nilai penjualan pada waktu tertentu, misalnya satu hari, satu minggu, satu bulan atausatu tahun. pada umumnya para pengusaha memperhitungkan pada setiap akhir bulan. Bag pengembangan usaha yang telah ada, besarnya omzet usaha yang diinginkan didasarkan pada penggalaman penjualan selama ini

\section{MATERI IV; Pengelolaan Pemasaran}

Pemasaran merupakan salah satu kegiatan-kegiatan pokok yang dilakukan oleh perusahaan-perusahaan kecil atau perusahaan besar untuk mempertahankan kelangsungan usaha hidupnya untuk berkembang dan mendapatkan laba. Arti pemasaran sering dikacaukan dengan pengertianpengertian : (1) penjualan, (2) perdagangan (3) distribusi. Padahal istilahistilah tersebut hanyalah merupakan satu bagian dari kegiatan pemasaran secara keseluruhan. Proses pemasaran itu dimulai jauh sebelum barangbarang diproduksi dan tidsak berakhir dengan penjualan. Kegiatan pemasaran hatus dapat juga memberikan kepuasan kepada konsumen jika menginginkan usahanya berjalan terus, atau konsumen mempunyai pandangan yang baik terhadap perusahaan.

Definisi yang paling luas dapat menerapkan secara jelas arti pentingnya pemasaran sebagai berikut :

Pemasaran adalah suatu sistem keseluruhan dari kegiatan-kegiatan usaha yang ditujukan untuk merencanakan, menentukan harga, mempromosikan dan mendistribusikan barang dan jasa yang dapat memuaskan kebutuhan baik pembeli yang ada maupun pembeli potensial.

Dari definisi di atas dapat diterangkan bahwa arti pemasaran jauh lebih luas dari pada arti penjualan. Pemasaran mencakup usaha perusahaan yang dimulai dengan mengidentifisir kebutuhan konsumen yang perlu dipuaskan, menentukan cara-caea promosi dan penyaluran/penjualan produk tersebut. Jadi kegiatan pemasaran adalah kegiatan-kegiatan yang saling berhubungan sebagai suatu sistem.

Kegiatan-kegiatan tersebut beroperasi didalam suatu lingkungan yang terus menerus berkembang sebagai suatu konsekwensi sosial. Bagi pemasaran perubahan lingkungan dapat merupakan tantangan baru yang 
Vol. 1, No. 1, Desember 2020

memerlukan tanggapan dan cara penyelesaian baru pula atau sebaliknya dapat berupa suatu peluang atau kesempatan mengembangkan usahanya.

Sehubungan dengan itu tugas kita yang akan melaksanakan pemasaran adalah memilih dan melaksanakan kegiatan pemasaran yang dapat membantu dalam pencapaian tujuan serta dalam penyesuaian diri dengan perubahan lingkungan. Kegiatan pemasaran itu haruslah dikoordinasi dan dikelola dengan cara yang baik, maka dikenalkan istilah pengelolaan pemasaran. Adapun definisi pengelolaan (manajemen) pemasaran adalah :

Penganalisisan, perencanaan pelaksanaan, dan pengawasan program-program yang bertujuan menimbulkan pertukaran dengan pasar yang dituju yang bermaksud untuk mencapai tujuan.

Titik berat diletakkan pada pemasaran dalam memenuhi kebutuhan dan keinginan pasar tersebut serta menentukan harga, mengadakan konsumsi dan distribusi yang efektif untuk memberitahu, mendorong serta melayani pasar.

Jadi pengelolaan pemasaran dirumuskan sebagai suatu proses manajemen yang meliputu penganalisaan, perencanaan, pelaksanaan dan pengawasan kegiatan pemasaran. Kegiatan ini bertujuan menimbulkan pertukaran yang diinginkan, baik yang menyangkut barang dan jasa atau benda-benda lain yang dapat memenuhi kebutuhan psikologis, sosial dan kebudayaan. Proses pertukaran dapat ditimbulkan baik oleh penjual, maupun pembeli yang menguntungkan kedua belah pihak. Penentuan produk, harga, promosi dan tempat untuk mencapai tanggapan yang efektif disesuaikan dengan sikap dan perilaku konsumen, dan sebaliknya sikap dan perilaku konsumen dipengaruhi sedemikian rupa sehingga menjadi sesuai dengan produk-produk atau barang yang dihasilkan.

Konsep pemasaran adalah sebuah falsafah bisnis yang menyatakan bahwa pemuasan kebutuhan merupakan syarat ekonomi dan sosial bagi kelangsungan hidup perusahaan (baik perusahaan kecil maupun perusahaan besar).

\section{Tiga unsur pokok pemasaran adalah :}

1. Orientasi Pada Konsumen

2. Penyusunan Kegiatan Pemasaran Secara Integral

3. Kepuasan Konsumen 
Faktor yang menentukan apakah perusahaan dalam jangka panjang akan mendapatkan laba ialah sedikitnya kepuasan konsumen yang dapat dipenuhi. ini tidaklah berarti bahwa perusahaan harus berusaha memaksimisasikan kepuasan konsumen. tetapi perusahaan harus mendapatkan laba dengan cara memberikan kepuasan kepada konsumen.

Perkembangan masyarakat dan teknologi telah menyebabkan perkembangan konsep pemasaran. Sekarang perusahaan dituntut untuk dapat menggapai cara-cara atau kebiasaan-kebiasaan masyarakat. Perusahaan tidak lagi berorientasi pada konsumen saja, tetapi harus juga berorientasi pada masyarakat. "Dengan pemasaran baru" ini disebut "konsep pemasaran". Perusahaan berusaha memberikan kemakmuran kepada konsumen dan masyarakat untuk jangka panjang.

\section{HASIL PEMBAHASAN}

Peserta penyuluhan adalah Ibu ibu yang melakukan usaha indudtri kerajinan rumah tangga, yang sekarang memulai lagi usahanya dengan peralatan dan modal yang ada setelah tahun kemarin terkena bencana gempa bumi yang telah merusak sebagian besar perlatan modal mereka. Sekarang mereka menggunakan peralatan yang tersisa dan dengan modal atau dana yang ada. Dari hasil diskusi juga diperoleh informasi bahwa, ada diantara mereka dulu sebelum bencana gempa memproduksi Nata Decoco, sekarang memproduksi kerupuk dengan peralatan yang tersisa untuk mempertahankan usaha dan hidup mereka

Peserta mendapatkan pengetahuan yang sangat mendasar mengenai aspek-aspek yang sangat dibutuhkan dalam manajemen keuangan / pembukuan, meliputi pengetahuan mengenai : 1). Manajemen Wiraswasta, 2). Pembukuan dan Administrasi, 3). Metode pengembangan Usaha dan 4). Tehnik mendapatkan Modal Kerja

Kegiatan pengabdian pada masyarakat ini dikatakan berhasil , dilihat dari banyaknya peserta yang hadir dan semangat serta antusiasnya mereka dalam mengajukan pertanyaan pada saat sesi diskusi. Hampir semua peserta mengajukan pertanyaan dan mengemukakan permaslahan yang mereka hadapi, seperti belum adanya catatan keuangan yang masuk dan keluar serta masih digabungkannya uang usaha dan uang rumah tangga, sehingga sulit diketahui apakah mereka mengalami untung atau rugi. Mereka merasakan adanya keuntungan dari usaha, karena mereka bisa mengembangkan usahanya kearah yang lebih baik dari sebelumnya, 
Vol. 1, No. 1, Desember 2020

dan bisa dilihat dari kepemilikan asset rumahtangga mereka yang sudah bertambah dan lebih berkualitas dari sebelumnya. Peserta dengan semangat dan antusiasnya mengikuti acara ini sampai selesai.

Dari hasil diskusi para peserta beringinan untuk mulai mencatat uang yang masuk dan keluar sehingga diketahui apakah mereka memperoleh kuntungan atau mengalami kerugian. Disamping itu adanya keingin mereka untuk memisahkan uang rumahtangga dengan uang usaha, agar usahanya berjalan dengan baik dan sukses.

Kegiatan penyuluhan dapat terlaksana dengan lancar, tidak lepas dari adanya faktor pendorong, yakni peserta penyuluhan dalam melaksakan kegiatan ini merupakan modal

\section{KESIMPULAN DAN SARAN}

\section{Kesimpulan}

1. Dengan memahami dan mengetahui arti dan manfaat administrasi usaha, mereka akan dapat mengurangi atau terhindar dari kesalahankesalahan yang pernah mereka lakukan selama ini, disamping itu mereka juga akan dapat mengetahui keberhasilan dari usaha yang mereka lakukan.

2. Dengan administrasi dan pembukuan yang rapi dan baik, akan dapat memberikan kemudahan bagi mereka untuk melakukan suatu perencanaan dimasa akan datang dan dapat memperbaiki kesalahan yang pernah mereka lakukan.

3. Perencanaan dan pengelolaan keuangan yang baik sebagai alat kendali yang dapat mengingatkan untuk melakukan sesuatu yang terbaik bagi usaha yang mereka jalani.

\section{Saran-Saran}

1. Kegiatan penyuluhan ini baru diikuti oleh sebagian kecil dari ibu ibu yang tergabung dalam kelompok industri rumahtangga, maka dirasa perlu untuk melaksanakan kegiatan yang bersifat praktek lapangan dalam arti penyuluhan yang disertai praktek ( Simulasi ) dengan jumlah peserta yang lebih banyak dan dalam waktu yang relatif lama sehingga masyarakat, khususnya para ibu ibu yang tergabung dalam kelompok ini, agar mengetahui secara langsung kegiatan penyuluhan. 
2. Keadaan ini bisa terlaksana bila didukung oleh dana yang lebih memadai dan mengadakan kerjasama dengan Departemen Perdagangan dan Perindsutrian (Deperindag ) Kabupaten Lombok Utara, agar pada kegiatan selanjutnya dapat ditindaklanjuti dengan pelaksanaan pendidikan dan pelatihan serta pembinaan terhadap obyek yang sama pada kegiatan selanjutnya dimasa mendatang.

\section{UCAPAN TERIMA KASIH ;}

Kegiatan Pengabdian kepada Masyarakat ini bisa terlaksana dengan baik, lancar dan sukses berkat kerjasama yang baik para pihak yang terkait. Pada kesempatan ini, Tim Pengabdian Kepada Masyarakat Fakultas Ekonomi dan Bisnis Universitas Mataram mengucapkan Terima kasih kepada:

1. Bapar Rektor, Universitas Mataram, yang telah memberikan dana untuk kegiatan Pengabdian Kepada Masyarakat ini

2. Ketua Lembaga Penelitian dan Pengabdian Pada Masyarakat ( LPPM), Universitas Mataram, yang telah menfasilitasi kegiatan pengabdian kepada masyarakat ini.

3. Dekan Fakultas Ekonomi dan Bisnis Universitas Mataram yang telah memberikan izin kepada Tim untuk melakukan kegiatan pengabdian di Desa Medane Kecamatan Tanjung Kabupaten Lombok Utara.

4. Bapak Kepala Desa Medane, Staf Desa dan para Kadus yang telah memberikan izin kepada Tim Pengabdian Kepada Masayarakat FEB Universitas Mataram untuk melakukan kegiatan ini.

5. Kepada Ibu Ibu peserta penyuluhan yang tergabung dalam Kelompok Industri Rumahtangga di Desa Desa Medani

6. Kepada pihak yang tidak bisa disebutkan satu persatu.

Hanya ucapan terima kasih yang bisa kami sampaikan, semoga kegiatan penyuluhan ini bermanfaat bagi masyarakat umum dan khususnya Ibu ibu yang tergabung dalam Kelompok Usaha Rumahtangga. Harapan kami Tim Pengabdian Kepada Masyarakat FEB Universitas Mataram, agar kegiatan yang sama bisa terlasana dalam skala yang lebih luas dan dengan peserta yang banyak. 